\title{
First report of Neofusicoccum parvum causing leaf spot of Scaevola taccada in China
}

\author{
Min $\mathrm{Li}^{1} \cdot \mathrm{Yi} \mathrm{Wang}^{2,3} \cdot$ Deqiang Gong ${ }^{1} \cdot$ Chao Zhao $^{2,3} \cdot$ Meijiao Hu$^{1}{ }^{1}$ \\ Received: 9 April 2020 / Accepted: 25 July 2020 / Published online: 3 August 2020 \\ (C) Società Italiana di Patologia Vegetale (S.I.Pa.V.) 2020
}

Keywords Neofusicoccum parvum $\cdot$ Leaf spot $\cdot$ Scaevola taccada

During a survey of diseased native plants in Xisha Islands, China from May 2018 to June 2019, a disease was mainly observed in lower leaves of Scaevola taccada. Early symptoms were water-soaked lesions in the leaf margin that later turned into yellowish-brown with dense black dots. Fragments of symptomatic leaves were surface-sterilized with $1 \%$ $\mathrm{NaClO}$, plated on potato dextrose agar, and incubated at $25^{\circ} \mathrm{C}$ in the dark. Morphologically similar colonies were isolated from all samples after $72 \mathrm{~h}$ incubation. The isolate ZD51 was selected for further pathogenicity test and identification. Pathogenicity test was conducted in triplicate by inoculating 10 mature wounded leaves of $S$. taccada with $20 \mu \mathrm{L}$ of a conidial suspension $\left(10^{6}\right.$ conidia/mL). The negative control was inoculated with sterile water. The inoculated leaves were maintained at $25{ }^{\circ} \mathrm{C}$ with $85 \%$ relative humidity in a growth chamber. Characteristic water-soaked lesions were observed 3 days after inoculation only on inoculated leaves. The same fungus was reisolated from the lesions, thus fulfilling Koch's postulates. Fungal colonies were circular, fast-growing and with abundant white aerial mycelium which turned into olivaceous- to dark-grey. After 20 days, black globular pycnidia were developed. Conidia were hyaline, unicellular, thin-walled with smooth surface, ellipsoid with round apices, and measuring $12.5-21.5(17.3 \pm 2.2) \mu \mathrm{m} \times 4.6-7.0(5.7 \pm 0.5)$ $\mu \mathrm{m}(N=100)$. Identification was performed by partially

Min Li and Yi Wang contributed equally to this work.

Meijiao $\mathrm{Hu}$

humeijiao320@sina.com

1 Environment and Plant Protection Institute, Chinese Academy of Tropical Agricultural Sciences, Haikou 571101, China

2 School of Life and Pharmaceutical Sciences, Hainan University, Haikou 570228, China

3 Key Laboratory of Tropical Biological Resources of Ministry of Education, Hainan University, Haikou 570228, China sequencing the internal transcribed spacer (ITS) region, and the translation elongation factor $1-\alpha(E F 1-\alpha)$ and $\beta$-tubulin (TUB) genes using the primers ITS4/ITS5 (White et al. 1990), EF1-728F/EF1-986R (Carbone and Kohn 1999) and BT-2a/ BT-2b (Glass and Donaldson 1995), respectively. The obtained sequences were deposited in GenBank (MN378364, MN850332, MN850331). Nucleotide BLAST analyses showed common $99 \%$ similarity with Neofusicoccum parvum for ITS (EU860378), EF1- $\alpha$ (MK088732), and TUB (MG879024), respectively. To our knowledge, this is the first report of $N$. parvum causing leaf spot of S. taccada in China.

Acknowledgements This study was supported by the Ministry of Agriculture and Rural Affairs, P. R. China (No. NFZX2018).

\section{References}

Carbone I, Kohn LM (1999) A method for designing primer sets for speciation studies in filamentous ascomycetes. Mycologia 91(3): 553-556

Glass NL, Donaldson GC (1995) Development of primer sets designed for use with the PCR to amplify conserved genes from filamentous ascomycetes. Appl Environ Microbiol 61(4):1323-1330

White TJ, Bruns T, Lee S, Taylor J (1990) Amplification and direct sequencing of fungal ribosomal RNA genes for phylognetics. In: Innis MA, Gelfand DH, Sninsky JJ, White JW (eds) PCR protocols: a guide to molecular methods and applications. Academic Press, San Diego, pp 315-322

Publisher's note Springer Nature remains neutral with regard to jurisdictional claims in published maps and institutional affiliations. 